\begin{tabular}{c} 
International Journal of Engineering \& Technology, $7(4)(2018) 2651-2654$ \\
International Journal of Engineering \& Technology \\
SPC \\
$\begin{array}{c}\text { Website: } \text { www.sciencepubco.com/index.php/IJET } \\
\text { doi: } 10.14419 / \text { ijet. } v 744.10381 \\
\text { Research paper }\end{array}$ \\
\hline
\end{tabular}

\title{
The environment coefficients effect on I-V and P-V characteristics curves of photovoltaic cell using Matlab/Simulink
}

\author{
Bashar Mohammed Salih $^{1}$ *, Rasha A. Mohmeed ${ }^{1}$, Mohammed Ahmed Ibrahim ${ }^{1}$ \\ ${ }^{1}$ Technical College of Mosul \\ *Corresponding author E-mail: Basharms1974@yahoo.com
}

\begin{abstract}
Many parameters and environments conditions will affect the behavior of the photovoltaic cell. This paper investigates, theoretically the variation of each temperature and irradiation effects on the output of the photovoltaic cell characteristics. Modeling of the photovoltaic cell scheme essentially requires taking weather data (temperature and irradiance) as input variables. The photovoltaic outputs are the current, voltage and power. Though, conclude the characteristics I-V or P-V desires of these important variables. Any variation in the entries directly shows variations in outputs. The characteristic curves are obtained with the use practical readings and measurements are illustrated directly from the solar power plant in the Technical Engineering College of Mosul. The complete modeling is then computergenerated using MATLAB/Simulink software owing to its common use and its helpfulness.
\end{abstract}

Keywords: PV Cell; Solar Cell; Single Diode; I-V and P-V Characteristics; $P V$ Temperature PV Irradiation.

\section{Introduction}

Solar energy was the one of the important energy resources in the last year's decades. The technology that directly converts free solar energy in to electrical energy without causing any pollution to the environment is termed as photovoltaic cell power generation [1] and [2].

Solar cell is manufactured of a semiconductor layer as like the PN junction diode, it converts the sun light in to electricity by photovoltaic behavior. The consumer, naturally, wants to run the Photovoltaic (PV) array at its maximum energy adaptation output by continuously using the maximum offered solar power of the array [3 and 4]. To have a scientific model of the photovoltaic cell, and to understand the highly nonlinearity behavior from semiconductor PN-junction, several models of equivalent circuits were developed, the single-diode model was simulated to realized and understand the mathematical and physical properties of the solar cell. Mathematical equations developed for modeling the performance of the PV generator are based on current-voltage characteristic of the modules [5] and [6].

\section{The mathematical model of photovoltaic cell}

Single-diode represents the best model according to the simplicity and accuracy of these models. To obtain the equivalent circuit equations, a mathematical analysis steps must be established [7].

\subsection{Ideal single-diode equivalent circuit}

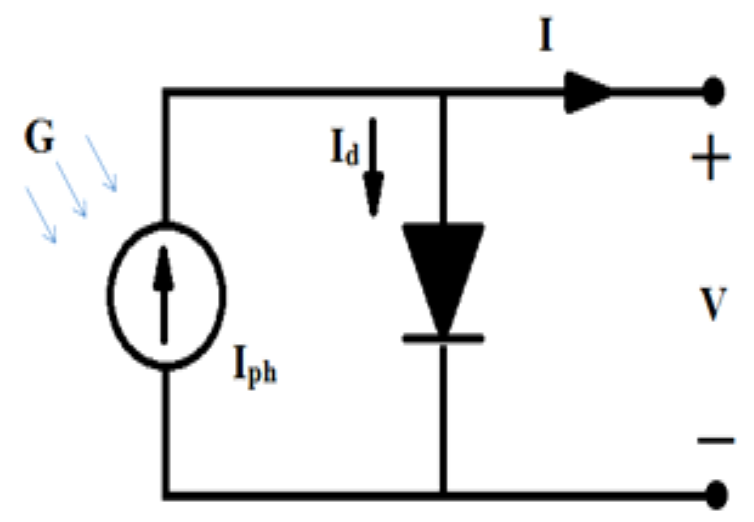

Fig. 1: Photovoltaic Cell Equivalent Circuit.

An ideal single-diode circuit is depicted in figure (1)

This equivalent circuit can be described as:

By applying Kirchhoff's law

$$
\mathrm{I}=\mathrm{I}_{\mathrm{ph}}-\mathrm{I}_{\mathrm{d}}
$$

As

$$
I_{d}=I_{0}\left(e^{\frac{v}{n_{s} v_{T}}}-1\right)
$$

Where

$$
\mathrm{V}_{\mathrm{T}}=\frac{\mathrm{nkT}}{\mathrm{q}}
$$

\subsection{Practical single-diode equivalent circuit}


For many literatures as in figure 2 this equivalent circuit is also termed as five unknown parameters $\left(\mathrm{n}, \mathrm{I}_{\mathrm{ph}}, \mathrm{I}_{0}, \mathrm{R}_{\mathrm{p}}\right.$ and $\left.\mathrm{R}_{\mathrm{s}}\right)$.

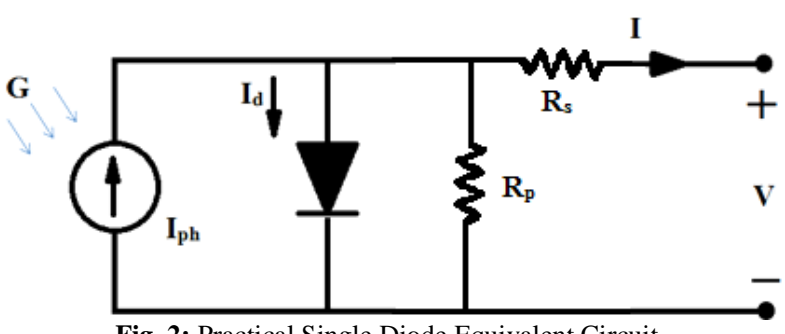

Fig. 2: Practical Single Diode Equivalent Circuit.

The photovoltaic current can be estimated by the following nonlinear equation

$I=I_{p h}-I_{0}\left(e^{\frac{v}{n_{s} V_{T}}}-1\right)-\frac{V+I R_{s}}{R_{p}}$

At open circuit situation:

$\mathrm{I}=0$

Hence,

$0=I_{p h}-I_{0}\left(e^{\frac{\mathrm{V}_{o c}+I R_{s}}{n_{s} V_{T}}}-1\right)-\frac{V_{o c}+I R_{s}}{R_{p}}$

At short circuit situation:

$\mathrm{I}=\mathrm{I}_{\mathrm{sc}}$

Hence,

$I_{s c}=I_{p h}-I_{0}\left(e^{\frac{I_{s c R s}}{n_{s V_{T}}}}-1\right)-\frac{I_{s c} R_{s}}{R_{p}}$

At maximum power point situation:

$I_{m p}=I_{p h}-I_{0}\left(e^{\frac{v_{m p}+I_{m p} R_{s}}{n_{s} V_{T}}}-1\right)-\frac{V_{m p}+I_{m p} R_{s}}{R_{p}}$

\section{Modeling of PV cell}

The PV model is simulated using Matlab/Simulink based on equations (1-9) and table 1. The PV model is (LCR-M200-JA-SI). Figure (3) shows the electrical circuit of the PV cell. The simulation of $\mathrm{I}-\mathrm{V}$ and $\mathrm{P}-\mathrm{V}$ characteristics curves can be produced by varying a certain parameter with making others constant. In this paper the effect of environmental temperature and irradiation are discussed.

Table 1: Electrical Parameters of (LCR-M200-JA-SI)

\begin{tabular}{ll}
\multicolumn{2}{c}{ Table 1: Electrical Parameters of (LCR-M200-JA-SI) } \\
\hline Dimensions & $1580 \times 808 \times 40 \mathrm{~mm}$ \\
\hline Weight & $15.5 \mathrm{~kg}$ \\
Cell number & 72 monocrystallian \\
$\mathrm{P}_{\mathrm{m}}$ & $200 \mathrm{WP}$ \\
$\mathrm{V}_{\mathrm{m}}$ & $37.26 \mathrm{~V}$ \\
$\mathrm{I}_{\mathrm{m}}$ & $5.37 \mathrm{~A}$ \\
Short circuit current & $5.66 \mathrm{~A}$ \\
Open circuit voltage & $45.62 \mathrm{~V}$ \\
\hline
\end{tabular}

\subsection{PV characteristics under different temperature conditions}

As the irradiation maintained constant at $1000 \mathrm{~W} / \mathrm{m}^{2}$, the temperature was varied as $\left(20^{\circ} \mathrm{C}\right.$ to $\left.80^{\circ} \mathrm{C}\right)$ by $20^{\circ} \mathrm{C}$ steps. The curves of V-I and P-V curves are as shown in figure (5). The generated current that produced by the incident sun light $\left(\mathrm{I}_{\mathrm{sc}}\right)$ will stay slightly increased and can be neglected, as well as the temperature increase. The output voltage $\left(\mathrm{V}_{\mathrm{oc}}\right)$ will changed and decreases. The temperature increase will decrease the voltage and hence the power [10]. 

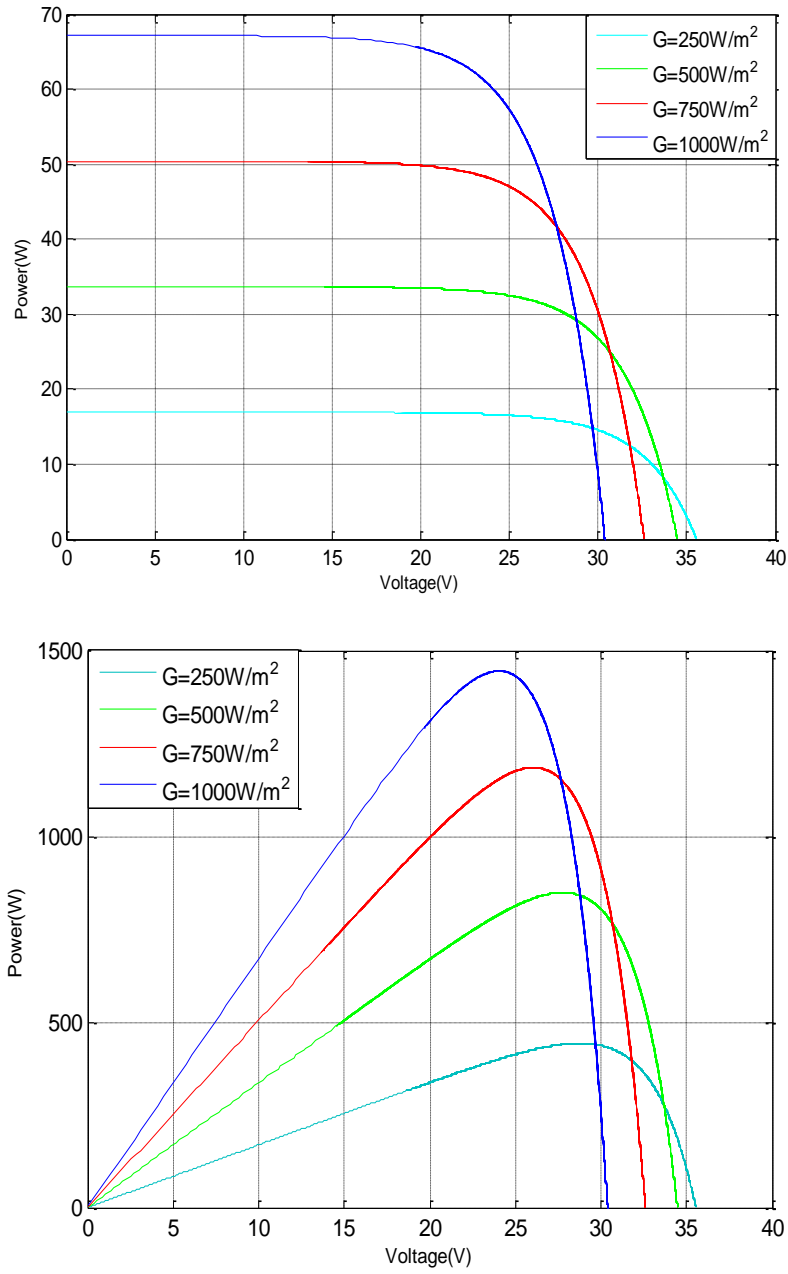

Fig. 5: Influence of Irradiation.

\section{Practical model of solar power plant}

The real practical structure of the solar power plant in the (Technical College of Mosul) is shown in figure (7 and 8).

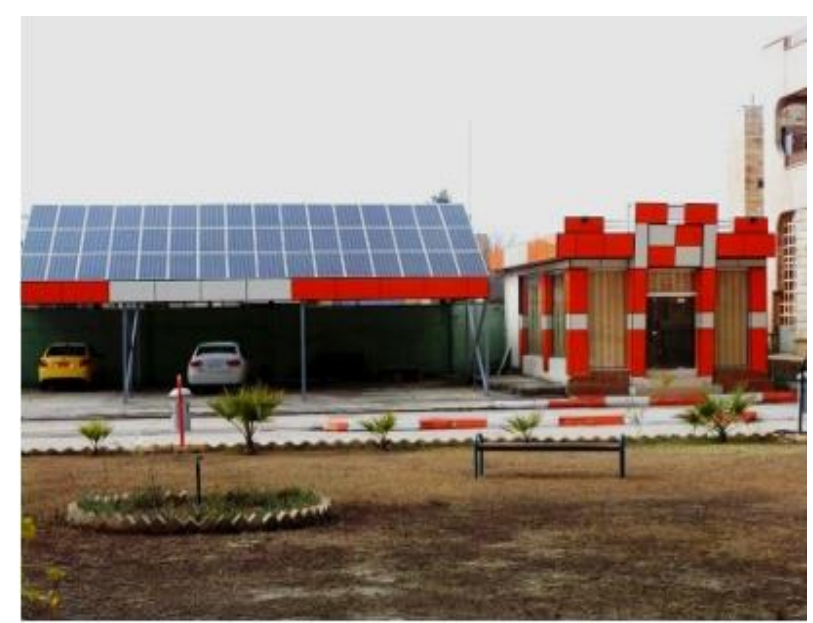

Fig. 6: The Real Practical Structure of the Solar Power Plant (Technica College of Mosul).

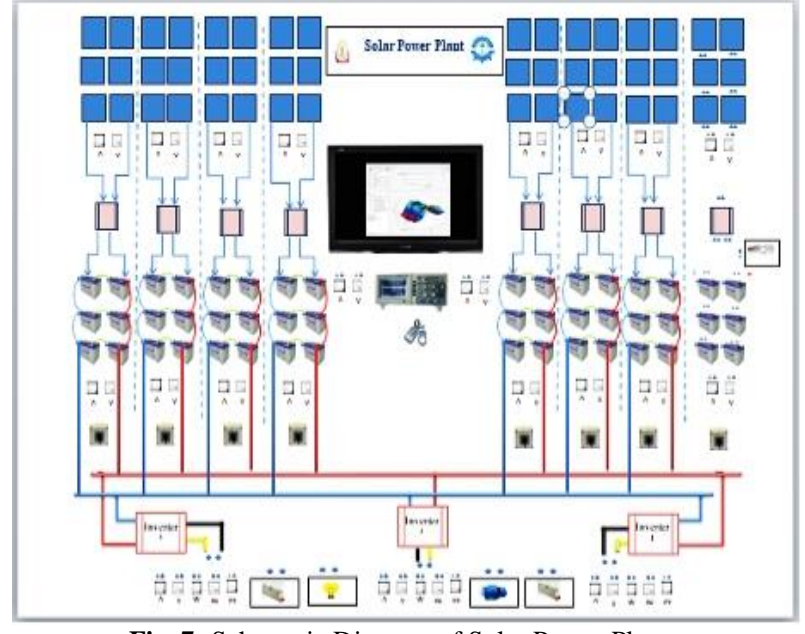

Fig. 7: Schematic Diagram of Solar Power Plamt.

\section{Practical results}

Table 2 and 3 shows the practical measurements of I-V and P-V characteristics that implemented on the Solar Power Plant in (Technical College of Mosul) with temperature influence.

The I-V and P-V curves are depicted in figure (9) at constant irradiation $\left(1000 \mathrm{~W} / \mathrm{m}^{2}\right)$. The related values of $\mathrm{I}-\mathrm{V}$ and $\mathrm{P}-\mathrm{V}$ curves of solar cell at irradiation of $1000 \mathrm{~W} / \mathrm{m}^{2}$ and constant temperature of $25^{\circ} \mathrm{C}$ are shown in table 4 and 5 .

Table 2: I-V Characteristics at 1000W/M2

\begin{tabular}{ll}
\hline Current $(\mathrm{A})$ & Voltage $(\mathrm{V})$ \\
\hline 66.5 & 0 \\
66.25 & 5 \\
66 & 10 \\
65.8 & 20 \\
64 & 21.5 \\
62 & 23.5 \\
56 & 25 \\
50 & 27 \\
40 & 28 \\
30 & 28.5 \\
20 & 29 \\
5 & 30 \\
\hline
\end{tabular}

Table 3: P-V Characteristics at 1000W/M2

\begin{tabular}{ll}
\hline Power $\left(\mathrm{W} / \mathrm{m}^{2}\right)$ & Voltage $(\mathrm{V})$ \\
\hline 0 & 0 \\
250 & 3.8 \\
500 & 7.5 \\
750 & 11.5 \\
1000 & 15 \\
1250 & 19 \\
1450 & 23.5 \\
1400 & 26 \\
1200 & 27.5 \\
1000 & 28 \\
750 & 29 \\
500 & 29.5 \\
250 & 30 \\
\hline
\end{tabular}



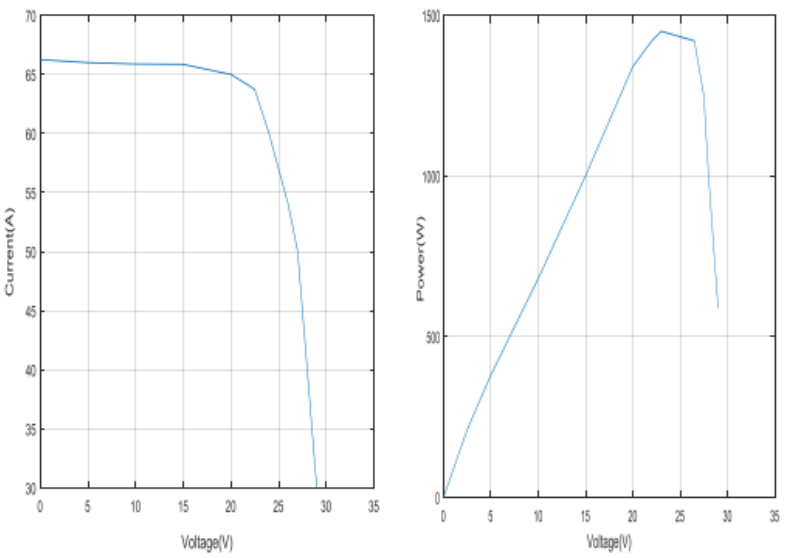

Fig. 9: Practical Influence of Temperature.

The influence of irradiation at constant temperature are shown in figure 10. These values are measured practically from the solar power plant in Technical College of Mosul.

Table 4: I-V Characters-Tics at 250C

\begin{tabular}{ll}
\hline Current $(\mathrm{A})$ & Voltage $(\mathrm{V})$ \\
\hline 66.52 & 0 \\
66 & 5 \\
65.88 & 10 \\
65.85 & 15 \\
65 & 20 \\
64 & 22 \\
63.7 & 22.5 \\
60 & 24 \\
57 & 25 \\
54 & 26 \\
50 & 27 \\
40 & 28 \\
30 & 29 \\
\hline
\end{tabular}

Table 5: P-V Characteristics at 250C

\begin{tabular}{ll}
\hline Power $\left(\mathrm{W} / \mathrm{m}^{2}\right)$ & Voltage $(\mathrm{V})$ \\
\hline 0 & 0 \\
210 & 2.5 \\
380 & 5 \\
500 & 7 \\
680 & 10 \\
1000 & 15 \\
1340 & 20 \\
1420 & 22 \\
1450 & 23 \\
1420 & 26.5 \\
1250 & 27.5 \\
1000 & 28 \\
590 & 29 \\
\hline
\end{tabular}
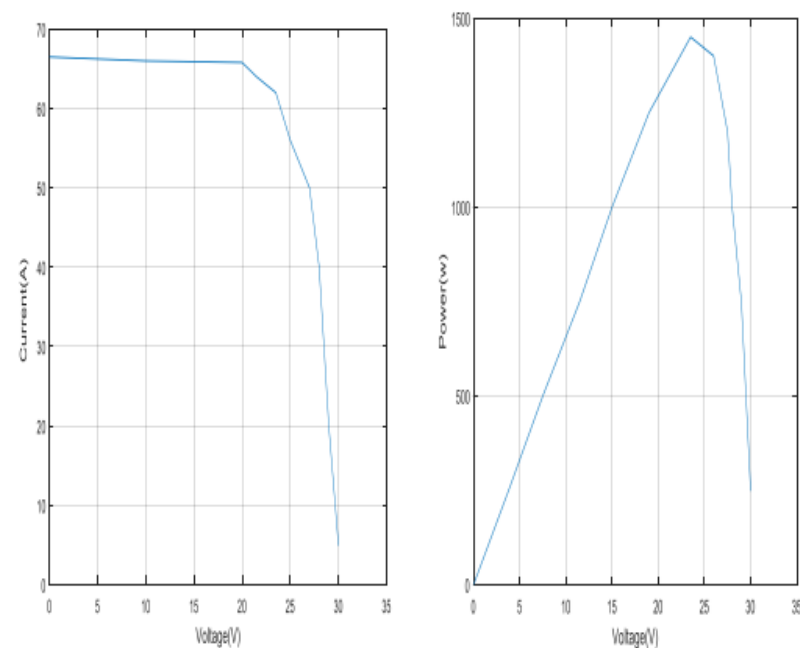

\section{Conclusion}

The proposed models of that simulated using Matlab/Simulink is gave a perfect result. The equivalent circuits are analyzed, the effects of the solar irradiation intensity and cell temperature as input. The output of photovoltaic cell is the I-V and P-V characteristics curves at various conditions.

As the increase in irradiation the photovoltaic cell output voltage will increase in slightly manner, also, higher magnitude of power will be produced. The change in temperature will affect the behavior of the solar cell, the output current will increase but in negligible value, while the output voltage will decrease, and this will affect the photovoltaic cell efficiency.

Through the results that obtained from each the equivalent circuit of single-diode, which described and modeled using the mathematical equations in Matlab/Simulink environments, and the results that measured and obtained directly from the Technical College of Mosul solar power plant obtainable that the effect of each change in the values of temperature and irradiation are identical quite through characteristics curves of I-V and P-V.

\section{References}

[1] Davud Mostafa Tobnaghi and Daryush Naderi, "The Effect of Solar Radiation and Temperature on Solar cells Performance", 2014 EJAS Journal-2015-3-2, 39-43

[2] J. Surya Kumari and Ch. Sai Babu, "Mathematical Modeling and Simulation of Photovoltaic Cell using Matlab-Simulink Environment", International Journal of Electrical and Computer Engineering (IJECE) Vol. 2, No. 1, February 2012, pp. 26 34.

[3] Vivek Tamrakar, S.C. Gupta and Yashwant Sawle, "Single-Diode PV Modeling and Study of Characteristics of Single and TwoDiode Equivalent Circuit", An International Journal (ELELIJ) Vol. 4, No. 3, August 2015.

[4] Guifang Guo, Xiaolan Wu, Shiqiong Zhouand Binggang Cao, "Modeling of Solar Photovoltaic Cells and Output Characteristic Simulation Based on Simulink", Journal of Chemical and Pharmaceutical Research, 2014, 6(7):1791-1795.

[5] Pradhan Arjyadhara1, Ali S.M2, Jena Chitralekha3, "Analysis of Solar PV Cell Performance with Changing Irradiance and Temperature", International Journal of Engineering and Computer Science ISSN, 2319-7242 Volume 2 Issue 1 Jan 2013 Page No. 214-220.

[6] Vivek Tamrakar, S.C. Gupta and Yashwant Sawlem "Single-Diode PV Cell Modeling and Study of Characteristics of Single and TwoDiode Equivalent Circuit", Electrical and Electronics Engineering: An International Journal (ELELIJ) Vol. 4, No 3, August 2015.

[7] Fawaz S. Abdullah, Safwan A. Hamoodi, Ali N. Hamoodi "Modeling of Electrical Characteristics of Photovoltaic and Effect of Cell Parameters on V-I Curve", International Journal of Engineering \& Technology, 7 (2.13) (2018) 276-280.

[8] Qais Mohammed Aish "Temperature Effect on Photovoltaic Modules Power Drop", Al-Khwarizmi Engineering Journal, Vol. 11, No. 2, P.P. 62- 73 (2015).

[9] Ababacar Ndiaye1, Cheikh M. F. Kébé, Pape A. Ndiaye, Abdérafi Charki.

[10] Abdessamad Kobi and Vincent Sambou "Impact of Dust on the Photovoltaic (PV) Modules Characteristics after an Exposition Year I Sahelian Environment: The Case of Senegal", International Journal of Physical Sciences, Vol. 8(21), pp. 1166-1173, 9 June 2013.

[11] M. Azzouzi, D. Popescu, M. Bouchahdane "Modeling of Electrical Characteristics of Photovoltaic Cell Considering Single-Diode Model", Journal of Clean Energy Technologies, Vol. 4, No. 6, November 2016.

Fig. 10: Practical Influence of Irradiation. 